\title{
KORTE MEDEDELINGEN
}

\section{Notes}

INAUguration OF THE PLANT BREEDING ESTABLISHMENT C.I.V.

In 1948 the Plant Breeding Establishment C.I.V. was founded by the cooperative buying and selling organizations of the Roman Catholic farmers' associations of the Netherlands. On July 5 th 1952 their breeding establishment on the estate Zelder at Ottersum (L.) was officially put into service.

The management rests in the hands of IR J. W. LACKAMP, aided in the breeding work by IR P. C. REEKERs (cereals and fodder beet) and Ir G. P. A. VAN DEN EYNDEN (hybrid corn and forage crops), while the improvement of potatoes and rye is entrusted to MR J. A. J. Poos at Veghel (N. Br.). The breeding program is especially directed toward the development of varieties of field crops adapted to sandy soils.

\section{E CONGRES VAN DE INTERNATIONALE POPULIERENCOMMISSIE}

Het 6 e congres van de Internationale Populierencommissie vond dit jaar plaats te Rome, van $26-$ 28 Mei 1952.

Hieraan was voorafgegaan een zitting van de Commission Permanente op 24 Mei.

Van 29-31 Mei werden excursies gehouden naar Napels, Salerno, Battipaglia, Isola, ter bestudering van de populierencultuur in $\mathbf{Z}$. Italië.

Veertien landen namen aan het congres deel, waarvan 9 als leden en 5 als waarnemers. Spanje werd als nieuw lid aangenomen.

De Heer Leloup, directeur van de afdeling Bosbouw van de F.A.O., nam als vertegenwoordiger van de Directeur-Generaal van de F.A.O. deel aan het congres en aan een gedeelte der excursies.

Prof. Pavari uit Florence vertegenwoordigde de Internationale Unie van Bosbouwproefstations.

The 6th Congress of the International Poplar Committee was held at Rome May 26 to 28, 1952.

G. Houtzagers

\section{NEWS ITEMS}

Ir N. H. H. AdDens, Superintendant of Agriculture, President of the Foundation for Agricultural Plant Breeding and President of the Central Organ for the Advancement of the Improvement and the Supplying of Propagating Material of Field Crops, has received the degree of doctor in agricultural science on a thesis entitled: Seeds and potatoes in Dutch Agriculture.

Ir C. W. C. van Beekom, Agricultural Adviser and formerly Technical Officer of the Netherlands Onion Federation, has received the degree of doctor in agricultural science on a thesis entitled: The influence of research on the development of the onion and shallot culture.

DR CHR. L. Rumke was appointed professor of genetics at the University of Utrecht.

IN MEMORIAM DR H. L. VAN de SANDE BaKHUYZEN

H. L. van de SANDE BakhuYzen was born on April 21, 1891. In 1924 he went to the U.S.A. where he worked at the Food Research Institute of Stanford University (California). In 1928 he became professor of botany at the State University of Arizona and in 1936 he returned to the $\mathrm{Ne}$ therlands. Here he continued his investigations on the physiology of growth and development. In 1937 appeared his book ,Studies on wheat grown under constant conditions". Among his other publications may be cited ,Flowering and flowering hormones in wheat" and ,Growth and production of sugar beets" (Verslagen van Landbouwk. Onderzoekingen $55 \mathrm{nr} 2,1950,227$ pp.).

He always took much interest in the breeding of cold resistant wheat varieties.

Dr van de Sande BakhuYzen died on April $17,1952$.

In memoriam Prof. Ir Hugo K. H. A. Mayer GMELIN

H. K. H. A. MAYeR GMElin, professor emeritus of Field Crop Husbandry at the Agricultural University of Wageningen died in August 1952 at the age of seventy-eight. Prof. MAYER GMELIN showed great interest in the improvement of grasses and clovers and for inbreeding in rye. Developing new forms of Dahlia in his own garden gave him great satisfaction. 